\title{
Aquaculture system diversity and sustainable development: fish farms and their representation
}

\author{
Jérôme Lazard ${ }^{1, a}$ Aurèle Baruthio ${ }^{1,2}$, Syndhia Mathé ${ }^{3}$, Hélène Rey-Valette ${ }^{3}$, Eduardo Chia ${ }^{4}$, \\ Olivier Clément ${ }^{5}$, Joël Aubin ${ }^{2}$, Pierre Morissens ${ }^{1}$, Olivier Mikolasek ${ }^{1}$, Marc Legendre ${ }^{6}$, Patrice Levang ${ }^{7}$, \\ Jean-Paul Blancheton ${ }^{8}$ and François René ${ }^{8}$
}

1 CIRAD, UR Aquaculture et gestion des ressources aquatiques, TA B-20/01, avenue Agropolis, 34398 Montpellier Cedex 5, France

2 INRA, UMR Sol Agronomie Spatialisation, 65 rue de St Brieuc, CS 84215, 35042 Rennes Cedex, France joel. aubin@inra.rennes.fr

3 Université de Montpellier 1, Faculté de Sciences économiques, CS 79606, 34960 Montpellier Cedex 2, France syndhia.mathe@univ-montp1.fr

4 INRA/CIRAD, UMR Innovation, 2 place Viala, 34000 Montpellier, France

chia@supagro.inra.fr

5 INRA, UMR Nuage, Pôle d'hydrobiologie, Quartier Ibarron, 34310 Saint Pée sur Nivelle, France clement@st-pee.inra.fr

${ }^{6}$ IRD, UR 175, Gamet, BP 5095, 34196 Montpellier Cedex 5, France

Marc.Legendre@ird.fr

7 IRD, UR 168, Jalan Taman Kemang 32B, Jakarta 12730, Indonesia

Patrice.Levang@ird.fr

8 IFREMER, chemin de Maguelone, 34250 Palavas-les-Flots, France

Jean.paul.blancheton@ifremer.fr

Received 14 January 2010; Accepted 18 May 2010

\begin{abstract}
Initiatives for the sustainable development of aquaculture have so far focused on the production of codes of conduct, of best management practices, of standards etc., most of which have been developed by international organisations, the industrial sector and non governmental organisations. They were, to a large extent, produced using a "top down" process and inspired by models from intensive industrial shrimp and sea fish farming (mainly salmon). However, most of global aquaculture production comes from small- and medium-sized farms, essentially in Asia which contributes $92 \%$ of the total world aquaculture production volume. The objective of this article is to define the contours of systemic typologies that are able to express the sustainability conditions of aquaculture systems. The proposed approach builds on surveys of aquaculture systems which differ in terms of their biogeographical nature (temperate/tropical and north/south countries) or their farming techniques and their governance systems. This work is a prerequisite to any attempt at an individualised and comparative evaluation of specific aquaculture systems from either global or territorial viewpoints. In order to go beyond the cleavage of a typology based on the differentiation between developed and developing countries, three typologies were produced. These typologies allow for discriminatory variables to be identified such as for example the marketing methods or the pace of innovation: a structural typology, a functional typology and a systemic typology. Finally, the representations of aquaculture activity and of its sustainability that producers have of the 4 different types that emerge from the systemic typology were recorded and analyzed.
\end{abstract}

Key words: Sustainable development / Sustainable aquaculture / Typology / Social representations

Résumé - Les initiatives de développement durable de l'aquaculture ont jusqu'à présent surtout consisté dans la production de codes de conduite, de guides de bonnes pratiques, de standards, etc., élaborés pour la plupart d'entre eux par des organisations internationales, le secteur industriel et des organisations non gouvernementales. Ces documents

a Corresponding author: jerome.lazard@cirad.fr 
ont largement été produits selon un processus de type «top down» et principalement inspirés par les modèles issus de l'aquaculture industrielle intensive de crevettes et de poissons marins (saumon principalement). Cependant, l'essentiel de la production de l'aquaculture mondiale provient d'exploitations de petite et moyenne taille, en Asie principalement qui contribue pour $92 \%$ au volume total de la production aquacole mondiale. Cette étude vise précisément à définir les contours de typologies globales aptes à rendre compte des conditions de durabilité des systèmes piscicoles. La démarche proposée s'appuie sur des enquêtes réalisées sur des systèmes de production différenciés tant sur les plans de la biogéographie (pays tempérés et tropicaux, du nord et du sud) que des techniques d'élevage mises en œuvre et des modes de gouvernance de ces systèmes. Ce travail constitue le préalable à toute tentative d'évaluation à la fois individualisée et comparative de la durabilité de systèmes aquacoles spécifiques tant sur les plans systémique que territorial. Afin de dépasser le clivage d'une typologie basée sur la différenciation entre pays développés et en développement, trois typologies ont été produites. Elles permettent l'identification de variables discriminantes telles que par exemple le mode de commercialisation de la production ou le rythme des innovations mises en œuvre : une typologie structurelle, une typologie fonctionnelle et une typologie globale. Enfin, les représentations de l'activité piscicole et de la durabilité de celle-ci que se font les producteurs des 4 différents types ressortant de la typologie globale ont été recueillies et analysées.

\section{Introduction}

Aquaculture has been the fastest growing animal food production globally for the last 3 decades, with production (excluding aquatic plants) growing at an average compounded rate of $8.1 \%$ per year since 1981 (compared with $3.0 \%$ for terrestrial farmed meat production; FAO 2008a, 2009). Although the aquaculture sector has now reached the level of capture fisheries in terms of food fish supply, it has not been without its problems and criticisms. The specific issues which have been raised by common critiques of aquaculture to highlight perceived unsustainable aquaculture practices and the potential negative impacts concern mainly (Tacon et al. 2010): 1) environmental issues such as mangrove destruction and habitat loss (Stickney and Mc Vey 2002), pollution of the aquatic environment (Tett 2008), escapes and genetic interactions with wild fish populations (Svasand et al. 2007; Chevassus-auLouis and Lazard 2009), use of non native species (Lazard and Lévêque 2009), use of fish meal and fish oil as major feed inputs (Naylor et al. 2000; Tacon and Metian 2008); 2) social and economic issues such as livelihood impacts and reduced access to community resources (Ronnback et al. 2002), displacement of coastal fishing and farming communities (Viswanathan and Genio 2001), social exclusion, social unrest and conflicts (Viswanathan and Genio 2001), conflicts with tourism, recreational and commercial fishing (Bodiguel and Rey-Valette 2006), disruption of seafood prices, local food supplies and food security (Dey et al. 2005; Wagner and Young 2009).

In these critiques, the fact that the great bulk of aquaculture production occurs in small and medium-sized farms, often farmer owned/rented and managed, particularly in Asia where $92 \%$ of global aquaculture production occurs, has almost always been neglected (Tacon et al. 2010). As a matter of fact, these critiques tend to equate all aquaculture development to shrimp and marine fish (mostly salmonid) farming ventures (De Silva and Davy 2009).

While most of the issues and impacts listed above are site and farm specific, considerable effort has recently been made, focused on the development of best management practices (BMPs), Codes of Conduct and aquaculture certification programs so as to show adherence to more environmentally responsible or sustainable farming practices (Allsopp et al. 2008;
Boyd et al. 2005, 2008; WWF 2007; Umesh et al. 2009; Belton et al. 2009). To date it has been largely industry through organizations and consortia, and non-government organizations that have taken the lead (World Bank 2007).

While this is certainly a step in the right direction, these codes and certification programs have usually focused only on the production level and as such have usually ignored the wider ecosystem, social and economical issues and are mainly the result of a "top down" process in which stake holders are poorly involved (Costa-Pierce 2002; Rey-Valette et al. 2008).

But the implementation of sustainable development presupposes the definition of a new value system and a new reference framework. These changes must first be discussed and negotiated between actors for them to be appropriated and put into practice. This deliberation process presupposes that actors' - both producers' and stakeholders' - representations of aquaculture have been understood (Jodelet 1989). It is therefore necessary to include a significant group of stakeholders for the implementation of sustainable development. This reinforces the current diversity of representations and requires taking into account the collective aspects of processes. Moreover, the taking into account of sustainable development should be an opportunity for the aquaculture sector to broaden its scale of analysis and to consider interactions with the territories where aquaculture farms are established.

Our main hypothesis is that, prior to any analysis, adapted typologies must be established that allow the inclusion of a wider diversity of determinant factors, in particular the types of interactions with, and impacts on, the territories and the levels and systems of governance which determine the effective implementation of new practices.

In line with this, the objective of this article is to identify a group of determinant variables concerning the sustainability of these systems, starting from the analysis of aquaculture systems which are very different from geographical, technical and social viewpoints. This work has been developed in relation to the interdisciplinary EVAD ("Evaluation of aquaculture systems sustainability") project whose purpose is to implement a generic construction procedure for aquaculture sustainable development indicators (Rey-Valette et al. 2008).

We first outline the main typologies as found in the literature. These show an evolution from technical approaches towards the integration of social factors. Then, we briefly 
describe the five sites under study which were selected so as to take into account a large and representative diversity of aquaculture systems. Then, we present the method for constructing a meta-typology including several typology construction logics. Finally, we present the results of the typologies and of the representations fish farmers have of their activity and of sustainable development. In the very last section, we discuss the interest of the presented approach.

\section{Typology uses: from structural to functional and systemic typology}

Aquaculture systems can be characterized by a great number of variables which can then be used for determining multiple typologies of differing utilities according to the questions to be answered and to the actors expressing these questions. The literature offers many examples of classifications and comparative analyses of aquaculture systems, which range from a simple descriptive list to complex typologies based on a significant sampling campaign and which have undergone a detailed statistical analysis.

\subsection{Typology evolution}

The most traditional (and oldest) classifications are based on agronomic criteria such as the type of production (fry, fish food, ornamental fish, etc.) or fish farming structure (cages, enclosed areas, ponds, etc.), on the size of the farms and on the intensification degree of the different production factors (extensive or intensive property, labour or input). Production volume and purpose criteria are used for distinguishing selfsubsistence fish farming from commercial or industrial fish farming. Based on predominantly "agro-economic" criteria (fish farming techniques and systems, production volumes and purpose, economic management of farms), Lazard et al. (1991) provide a classification for the different types of fish farming practices employed in sub-Saharan Africa. This classification is organized around four categories: self-sufficiency, "small" market oriented production, specialized-type fish farming and large-scale fish farming. Social and economic criteria have then been included progressively, such as property access conditions (ownership, tenant farming, share-crop system) as well as fish farmer characteristics (age, education, origin, gender, etc.). Property access conditions in relation to fish farming have been analyzed for example by Hejdova (2006) in an anthropological study conducted in the province of Pampanga in the Philippines. The author proposes a classification for shrimp farming systems based on the organization of social networks (favoured agreements, economic, moral relationships, etc.). An increasing number of diversified criteria are progressively integrated in typologies, which combine social, economic and technical factors. For example, this is the case for the typology developed by Pemsl et al. (2006) which aims to characterize aquaculture systems in Bangladesh and of identifying high potential areas. Three categories were defined: intensive systems, semi-intensive systems and improved extensive systems. However, most of the typologies which are available in the aquaculture field (mostly in the case of the oldest typologies such as the FAO typology for many countries and areas in the World) have been constructed based on scientific expertise without any previous sampling. This is the case for the typology developed by Yap (1999) which provides a classification for rural aquaculture in the Philippines based on the types of species (miscellaneous, seaweed, shellfish and fish) and farming systems. However, in order to provide a rigorous analysis, the diversification of selected criteria requires using sampling protocols ensuring the representativeness of the analyses. Thus, in 2002, the carp farming typology in Asia proposed by Michielsens et al. was based on a sampling campaign carried out in around 2500 farms from 9 countries and on a multifactor statistical analysis (main components, clusters).

\subsection{Typology uses and functionality}

It is possible to use typologies for producing summary information at different scales and according to various modalities which will facilitate sector management decision-making. Typologies may have a programmatic function comparable to that of the World Bank (2007) whose purpose is to identify constraints and conditions for promoting sustainable aquaculture in the developing countries of Africa and South America, based on a simple aquaculture system classification and associated entrepreneurial models. The aim is to improve the efficiency of public policies by defining sub-groups of different target populations. In other cases, typologies are a prerequisite for improving knowledge of aquaculture production systems. Thus, the typology of extensive aquaculture in coastal pond systems in the Philippines defined by Stevenson et al. (2007) is an intermediate result enabling the study of the cost efficiency of production factors within the different types of systems described. This is also the case for the fish farm typologies determined by Irz et al. (2004 and 2007), still in the Philippines, which are used for understanding the vulnerability of actor communities regarding poverty.

As regards sustainable development, it is possible to assume that structure criteria for aquaculture systems are not sufficient for identifying the types of fish farms which are the most compatible with sustainable development principles. In fact and as shown in this paper, structural criteria often refer to farm size but completely ignore the functional components of farms. These turn out to be a key factor for the implementation of sustainable development initiatives and for actor appropriation of such initiatives, the latter requiring that they be consistent with actor practices. In particular, taking into account regulatory systems (governance) enables the definition of a new approach. Analyzing the characteristics of these systems as regards sustainable development notably involves ignoring these major categories and proposing a functional typology for aquaculture systems based on factors related to production systems, fish farming, regulatory systems and their regional integration so as to study the internal sustainability of aquaculture farms and their contribution to the areas which they use. It is very important to identify the types of systems that are most likely to implement sustainable development, which itself implies actor participation in the joint building of a new common reference framework. 
Table 1. Position of aquaculture systems under study according to three criteria: environment, regulation and intensification.

\begin{tabular}{lcccc}
\hline & \multicolumn{2}{c}{ Rural area } & \multicolumn{2}{c}{ Coastal area } \\
\hline & Low & Stocking density & High \\
\hline Low regulation & $\begin{array}{c}\text { Ponds in Indonesia } \\
\text { Ponds in Cameroon }\end{array}$ & Cages in Indonesia & $\begin{array}{c}\text { Ponds in the } \\
\text { Philippines }\end{array}$ \\
\hline High regulation & & Trout farming in & & $\begin{array}{c}\text { Cages in the } \\
\text { Brittany, France }\end{array}$ \\
& & & $\begin{array}{c}\text { Mediterranean } \\
\text { region }\end{array}$ \\
\hline
\end{tabular}

\section{Generic analysis of aquaculture sustainability based on various types of aquaculture system}

In order to establish typologies based on a wide variety of contexts, six sites were selected, which were deliberately chosen to be very different from one another. This contrasted character, whose aim is to ensure the reliability of our approach, represents a methodological issue related to the characterization of this diversity.

\subsection{Site selection drivers}

Study systems were selected according to a structural matrix including three criteria which cross-check the main factors employed for characterizing aquaculture systems (Table 1). The first selected criterion is the type of environment, rural aquaculture systems being different from maritime aquaculture systems. The regional insertion of rural systems must be analyzed at the watershed scale with significant interactions with agriculture. The second type of system, which is located on the coast or in the open sea, is faced with major property conflicts, such as with tourism, at the ecosystem scale whose limits are diffuse. Constraint levels which are set by regulatory systems have then been taken into account. They are defined by institutional documents as well as by the diversity of appropriation procedures applied in aquaculture. This includes public, common and private areas which lead to various leasing organizations and procedures in multiple use contexts. These generate externalities and even use conflicts. These different regulatory procedures and levels often cover divisions existing between developed and developing countries due to the maturity and typology differences existing between regulatory systems, and to the different sensitivity levels of consumers and agents when taking into account the issues and conflicts related to economic growth and environmental protection objectives. Lastly, the intensification levels of production systems have also had an impact and can be briefly summarized by stocking densities expressed as biomass per unit structure volume (raceway, pond, and cage).

\subsection{Brief summary of sites under study}

\subsubsection{Rainbow trout farming in Brittany (France)}

Rainbow trout farming is an intensive farming system based on a high input level and on an increased stocking rate.
At present, in Brittany, the number of trout farms is decreasing, farms are being concentrated and the overall production is being reduced due to numerous constraints: environmental constraints, social constraints (farming activity acceptance, product image, etc.), regulatory and economic constraints (input cost variation, competition with salmon, etc.).

\subsubsection{Mediterranean sea bass and sea bream farming}

In order to satisfy a strong demand (tourists and indigenous population), the production of aquaculture fish (mainly sea bass and sea bream) started in 1980 and increased by $25 \%$ each year between 1990 and 2000 (the current production is estimated at 200000 tonnes per year).

Current production systems (consisting of sea-based cages or land-based raceways) are in conflict with tourism and other models will have to be developed (Rey-Valette et al. 2007). Due to recent crises, aquaculture activity has become concentrated as fish farms have been bought by major groups.

\subsubsection{Fish and shrimp farming in coastal ponds in the Philippines}

Fish farming plays a major role in the economy of the Philippines and coastal ponds, consisting essentially of extensive shrimp-fish polyculture, represent around $60 \%$ of the overall aquaculture production. Observing the development dynamics of Philippine aquaculture systems underlines the significant flexibility of extensive systems compared to the economic fragility of intensive fish farms when markets are saturated.

\subsubsection{Small scale fish farming in Indonesia}

In Indonesia, although freshwater fish farming is generally a small-scale activity, it nevertheless represents one of the highest yearly production rates in the world. Fish farming production systems with high input rates have rapidly developed locally over the last ten years: catfish in ponds in the Centre of Sumatra (Tangkit, Jambi province) and carps and tilapia in floating cages in the Cirata dam reservoir (West Java).

\subsubsection{Commercial fish farming in Family Agricultural Enterprises (EFA) in Western Cameroon}

Despite an increasing demand for fish, the history of fish farming in Cameroon (and more largely in Sub-Saharan 
Table 2. Fish farmer survey distribution by site.

\begin{tabular}{ccccccccccc}
\hline Brittany & & \multicolumn{3}{c}{ Indonesia } & \multicolumn{4}{c}{ Mediterranean region } & The & Total \\
\cline { 3 - 10 } France & Cameroon & Tangkit & Cirata & Total & Turkey & Cyprus & France & Total & Philippines & \\
\hline 8 & 13 & 29 & 27 & 56 & 9 & 4 & 8 & 21 & 30 & 128 \\
\hline
\end{tabular}

Table 3. Fish farmers' representations survey distribution by site and by type of fish farm.

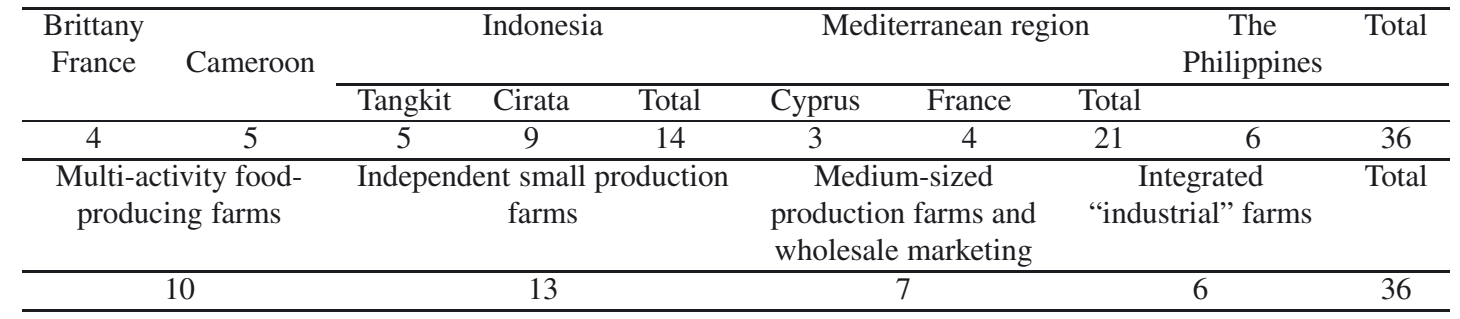

Africa) remains characterized by a marginal production which is most likely due to the fact that their farming systems are not sufficiently efficient from technical and socioeconomic points of view. The high plateaux in the Western region, which are characterized by a very dynamic diversification of agricultural production systems, represent one of the areas in Cameroon where the greatest number of fish ponds have been constructed with numerous fish farming innovations involving an input intensification.

\section{Methodological approach: material and method}

\subsection{General principles}

Before analysing the conditions underlying the implementation of sustainable development, two further types of investigation are necessary combining quantitative surveys to establish typologies and qualitative ones to analyze representations and perceptions. The latter are frequently used to adapt public policies to actors' requirements and context specificity. This type of association is frequent (Couty 1984; Kaplowitz 2000) and beneficial as quantitative and qualitative approaches complement each other. Questionnaires were adapted to the type of survey with a majority of closed questions when dealing with the farm survey and on the contrary open questions in the sociological survey on representations.

Firstly, in-depth surveys were carried out in farms using a common questionnaire for all sites. These surveys explored several themes 1) farm structure 2) farming practices (technique, labour) 3) marketing approaches 4) access to technology and information 5) management systems and rules 6) encountered conflicts and constraints. All stakeholders were then surveyed on representations of aquaculture and of sustainable development, essentially using open questions and interview guides adapted to each type of actor: producers, value chain actors (upstream and downstream), institutional actors (State, local authorities, research, associations). Open questions left the interviewee complete freedom in their answers. However, they were followed by semi-open questions which suggested choices within a range of categories. The idea was to address sustainable development, which is a broad concept that does not necessarily make sense for actors, in particular in isolated rural systems of developing countries or when actors have an institutional or political definition of sustainable development in mind with no link to their daily practices. The interviews were therefore structured in such a way as first to address the definitions and the possible consequences for the activity according to each dimension (environmental, economic, social and institutional) whilst keeping in mind that this dimensional approach is in itself a way to standardise the reference to sustainable development. As appropriate, questionnaires were translated into English or into the local language and validated by local partner researchers.

\subsection{Onsite surveys}

The sampling strategy was developed on the basis of an expert-opinion typology of the main types of aquaculture farm found in each area, so that the heterogeneity of size and of the sector's organisational mode could be addressed. The number of different types of farm was found to be inversely proportional to the unit staffing level. This led to fewer sampling strata in systems with the highest staff levels, that is for the two sites in Indonesia and the Philippines. The number of surveys per stratum was then calculated taking into account the fact that 1) these were frame surveys requiring prolonged interviews 2) human and financial resources to carry out the surveys were limited. Sociological surveys on representations were undertaken on all stakeholders (i.e. 168 persons for all the areas) and on a sample of producers (36 in total) who had already been the subject of a quantitative survey and were chosen as the most representative of the various groups. Tables 2 and 3 show the number of surveys carried out for the two types of survey in each site.

\subsection{Data processing}

These two survey methods also led to differences in the way data were analyzed: traditional statistical analysis for the farm survey and content analysis for the representation surveys. Quantitative surveys were analyzed both by area and for 
Table 4. Structure of the database common to all aquaculture systems.

\begin{tabular}{lc}
\hline Variable themes & $\begin{array}{c}\text { Number of } \\
\text { variables }\end{array}$ \\
\hline Type and degree of openness (to social and economic environment) & 8 \\
Management arrangements, margins and level of intermediate input & 15 \\
Origin (transmission) and family & 5 \\
Number of sites and size of units & 6 \\
Specialization and production cycle & 8 \\
Amount and kind of work involved & 5 \\
Know-how, training and information & 2 \\
Product diversification & 2 \\
Marketing systems & 5 \\
Projects & 10 \\
Regulatory level and system & 17 \\
Conflicts & 4 \\
Constraints and exploitation conditions & 3 \\
\hline Total & 90 \\
\hline
\end{tabular}

Table 5. Contribution of variables to the multiple correspondence analysis (MCA) axes.

\begin{tabular}{|c|c|c|c|c|}
\hline Name of variable & Number of modalities & \multicolumn{3}{|c|}{ Contribution of variable } \\
\hline \multicolumn{5}{|c|}{ Structural typology } \\
\hline & & $\begin{array}{l}\text { Axis 1 } \\
(29 \%)\end{array}$ & $\begin{array}{l}\text { Axis 2 } \\
(21 \%)\end{array}$ & $\begin{array}{l}\text { Axis 3 } \\
(14 \%)\end{array}$ \\
\hline Date of installation & 3 & 20.0 & 26.2 & 16.1 \\
\hline Production $(\mathrm{t})$ & 3 & 27.8 & l & 73.2 \\
\hline Number of various products & 3 & 26.9 & 26.0 & l \\
\hline Type of marketing & 3 & 25.4 & 44.2 & l \\
\hline \multicolumn{5}{|c|}{ Functional typology } \\
\hline & & $\begin{array}{l}\text { Axis 1 } \\
(29 \%)\end{array}$ & $\begin{array}{l}\text { Axis } 2 \\
(17 \%)\end{array}$ & $\begin{array}{l}\text { Axis } 3 \\
(14 \%)\end{array}$ \\
\hline Type of farm & 3 & 20.9 & 42.3 & T \\
\hline Number of associations or cooperatives & 3 & 27.9 & / & 34.8 \\
\hline Method of entry into the activity & 4 & 15.1 & 25.6 & 35.6 \\
\hline Rate of innovation & 3 & 12.4 & 21.6 & 29.2 \\
\hline Level of formal constraints related to the & 2 & 23.7 & / & \\
\hline \multicolumn{5}{|c|}{ Systemic typology } \\
\hline & & $\begin{array}{l}\text { Axis 1 } \\
(31 \%)\end{array}$ & $\begin{array}{l}\text { Axis 2 } \\
(19 \%)\end{array}$ & $\begin{array}{l}\text { Axis } 3 \\
(16 \%)\end{array}$ \\
\hline$\%$ of time devoted to aquaculture & 3 & 28.5 & / & 23.1 \\
\hline Type of farm & 3 & 18.4 & 21.4 & 37.6 \\
\hline Production $(\mathrm{t})$ & 3 & 32.3 & 49.1 & l \\
\hline Type of marketing & 3 & 20.7 & 27.1 & 34.0 \\
\hline
\end{tabular}

the areas as a whole using a common database which includes the main structuring variables (Table 4). The coding was harmonized to make global analysis possible for all the areas as a whole. Typologies were developed from multiple correspondence analyses carried out from this common basis. Several iterations were required to characterize aquaculture systems in terms of fish farm sustainability and contribution to regional sustainability. Table 5 summarizes the statistical characteristics of the three analyses carried out successively to develop the structural, functional and systemic typologies.

As regards the qualitative survey, following the textual analysis, a matrix of coded answers was established to calculate frequency indices and carry out statistical analysis in order to characterize representation categories.

\section{Results}

\subsection{A series of nested typologies to overcome the developed/developing country cleavage}

\subsubsection{Local typology comparison for each site}

Firstly, fish farm typologies were determined independently for each site (Table 6). Common factors were identified for the first three variables involved in typologies by comparing the discriminating factors within each of the sites:

- the type of capital (external or family-related) or exploitation arrangements (ownership or lease) which represents the first explanatory factor (except for Cameroon); 
- the marketing approach which, for certain categories, means that the sector is integrated in the industry (or commodity chain);

- the size of farms under assessment according to volumes and/or production capacities.

Site-specific factors were only observed for variables ranked in fourth position.

\subsubsection{Systemic typology at the scale of the six sites}

Ninety common variables were identified in the database (Table 4) and 25 discriminating variables were initially selected (10 variables which are homogeneous within the sites and discriminating from one site to another and 15 variables which are discriminating within each site and from one site to another). All of these variables were processed (multiple component analysis), the result being that sites were divided among developed countries and developing countries. In order to avoid this obvious cleavage, variables were separated into two groups according to whether they were structural or functional. The aim was to determine more specific typologies and to enable inter-site associations based on smaller groups of variables and thus to carry out a progressive selection of the most discriminating variables. Three classes were finally obtained.

- A structural class with four variables (installation date, capacity produced, number of products and marketing approach); it highlights the significance of the size, the marketing approach and product diversification. Three types emerged: 1) small size, weakly diversified with retail sale and personal consumption (Cameroon and Indonesia), 2) medium and large size with a large range of products and wholesale marketing (Philippines and Indonesia), and 3) medium and large size with diversified products and markets (Mediterranean region and Brittany).

- A functional class with five variables (type of farm, number of associations or cooperatives, access mode to this activity, innovation pace, formal constraint level i.e. propertyrelated, access to water or right to produce). This farmlevel functional typology highlights the significance of the type of farming as well as their status in terms of management. Four types emerged: 1) traditional tenant farming (Philippines), 2) independent traditional (Indonesia and Cameroon), 3) independent developing (Mediterranean and Brittany), and 4) integrated developing (Mediterranean and Brittany).

- And lastly, a systemic class (Table 7) combining the most structuring 4 variables from both previous classes (time percentage in aquaculture, type of farm, production capacity and marketing approach). There were also divided into four types of units: multi-activity food-producing farms, independent small production farms, medium-sized production farms and wholesale marketing, integrated "industrial" farms.

Each of these three typologies offers classifications that go beyond the differences related to the sites and show the importance of the farm size and of some functional factors such as marketing methods, property arrangements and degree of control.

\subsection{Activity and sustainable development representations according to the types of aquaculture systems}

It should be recalled that representation surveys concerned how actors viewed (i) their current activity and the aquaculture sector, (ii) sustainable development and (iii) the means to be implemented in order to develop a sustainable aquaculture industry. By combining the entirely open questions and choices between predetermined options, analyses were performed based on textual studies and quantitative processing of coded questions. The analysis presented in this paper is restricted to fish farmers' representations. These surveys (concerning 36 producers - Table 3 ) were carried out according to the type of aquaculture system so as to identify representation differences according to the classification.

Except for small farms which are highly integrated in their areas and favour the social and environmental functions of the activity, converging representations are noted for $60 \%$ of fish farmers regarding the significance of the economic functions of the activity. Fish farming is considered as a profitable activity which favours economic development. The main characteristics of the representations according to aquaculture system typology are summarized in Table 8.

As regards the sustainability of fish farms and the actual definition of sustainable development, views varied according to the types of farm (Table 9). Perceptions varied mainly due to a lack of information on sustainable development and on its implementation. There was a relatively high non response rate for sustainable development questions $(60.5 \%$ on average). Despite the difficulty for fish farmers to formulate a sustainable development representation, they however understood relatively well the factors which could contribute to the sustainability of their activity.

\section{Discussion}

This typology was determined based on the following question: which aquaculture production systems can react positively to the implementation of a sustainable development approach? As sustainable development is a complex and multidimensional phenomenon, structural criteria are not sufficient to express this diversity. Building several nested typologies from a broad range of variables is a way to go beyond traditional oppositions for example between developed and developing countries, or covering technical aspects linked to farming practice. Our systemic typology reveals four broad types of units (multi-activity food-producing farms, independent small production farms, medium-sized production farms and wholesale marketing, integrated "industrial" farms). These categories attest to the various economic strategies depending on market size and type which determine the insertion into the territory of the types of stakeholder with whom the units are connected. Property arrangements are also significant as they introduce 


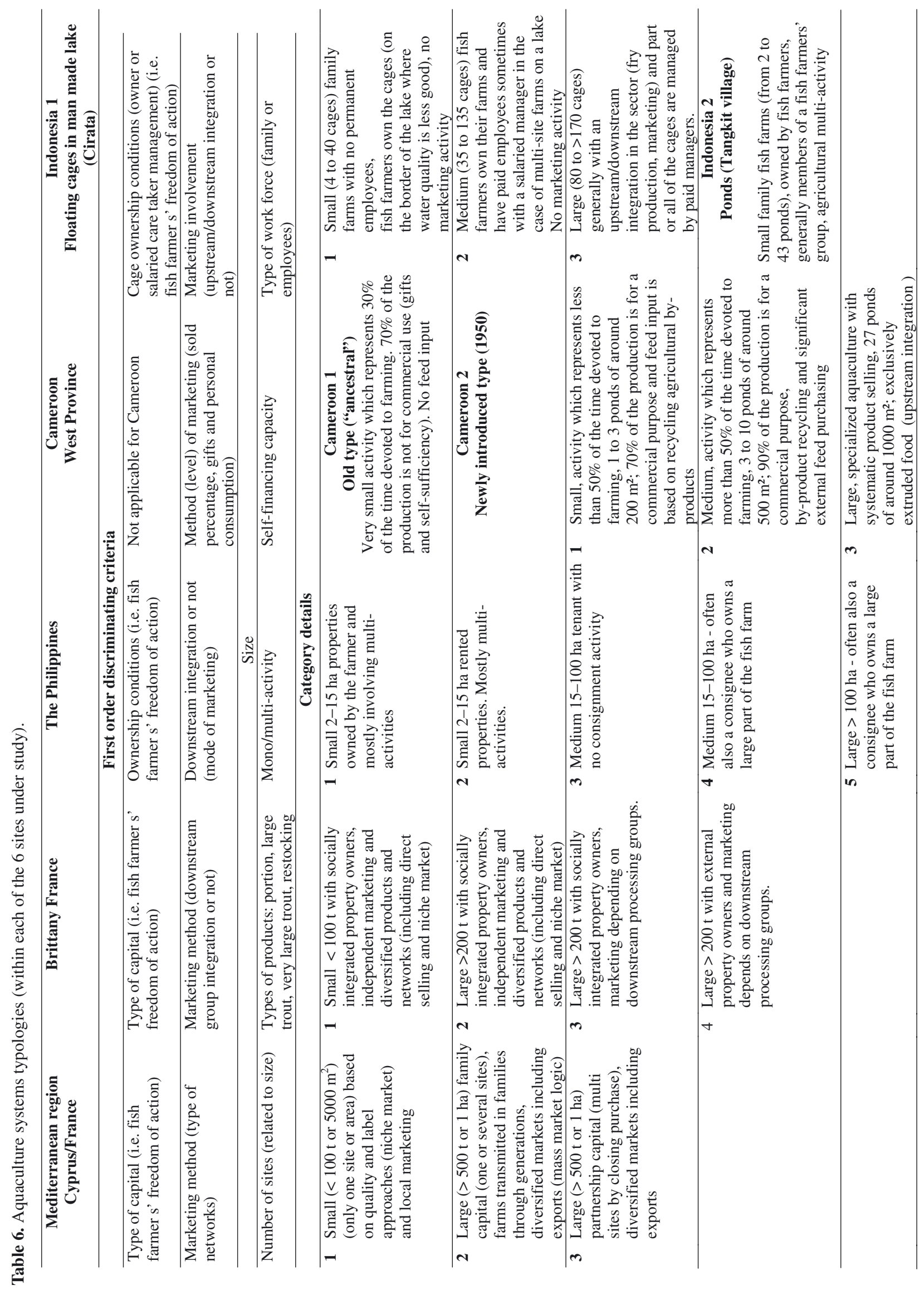


Table 7. Aquaculture system systemic typology.

\begin{tabular}{|c|c|c|c|}
\hline $\begin{array}{l}\text { Multi-activity food- } \\
\text { producing farms }\end{array}$ & $\begin{array}{l}\text { Independent small } \\
\text { production farms }\end{array}$ & $\begin{array}{l}\text { Medium-sized production } \\
\text { farms and wholesale } \\
\text { 'marketing }\end{array}$ & $\begin{array}{l}\text { Integrated } \\
\text { "industrial" farms }\end{array}$ \\
\hline $\begin{array}{l}\text { 1. Small production } \\
\text { 2. Retail marketing } \\
\text { 3. Less than } 50 \% \text { of } \\
\text { time devoted to } \\
\text { aquaculture }\end{array}$ & $\begin{array}{l}\text { 1. Independent type } \\
\text { ownership } \\
\text { 2. Medium production } \\
\text { 3. Wholesale and retail } \\
\text { marketing }\end{array}$ & $\begin{array}{l}\text { 1. Tenant farming type } \\
\text { 2. Wholesale marketing } \\
\text { 3. From } 50 \text { to } 80 \% \text { of time } \\
\text { devoted to aquaculture }\end{array}$ & $\begin{array}{l}\text { 1. Integrated ownership type } \\
\text { or belonging to industrial } \\
\text { group } \\
\text { 2. Large productions } \\
\text { 3. } 100 \% \text { of time devoted to aquaculture }\end{array}$ \\
\hline 11 farms $(10 \%)$ & 48 farms $(40 \%)$ & $\begin{array}{l}2 \text { farms } \\
(35 \%)\end{array}$ & $\begin{array}{l}18 \text { farms } \\
(15 \%)\end{array}$ \\
\hline including & $\begin{array}{l}\text { including } \\
\text { Indonesia 28/56 } \\
\text { The Philippines 11/30 } \\
\text { Brittany } 2 / 8\end{array}$ & $\begin{array}{l}\text { including } \\
\text { Indonesia 24/56 } \\
\text { The Philippines 17/30 }\end{array}$ & $\begin{array}{l}\text { including } \\
\text { Indonesia 4/56 } \\
\text { The Philippines 2/30 } \\
\text { Brittany 6/8 }\end{array}$ \\
\hline Cameroon 11/13 & $\begin{array}{l}\text { Cameroon } 2 / 13 \\
\text { Mediterranean region } 5 / 12\end{array}$ & Mediterranean region $1 / 12$ & Mediterranean region $6 / 12$ \\
\hline
\end{tabular}

Table 8. Summary of activity representations according to the type of aquaculture system.

\begin{tabular}{|c|c|c|c|}
\hline $\begin{array}{l}\text { Multi-activity food- } \\
\text { producing farms }\end{array}$ & $\begin{array}{l}\text { Independent small } \\
\text { production farms }\end{array}$ & $\begin{array}{l}\text { Medium-sized } \\
\text { production farms and } \\
\text { wholesale marketing }\end{array}$ & $\begin{array}{l}\text { Integrated "industrial" } \\
\text { farms }\end{array}$ \\
\hline $\begin{array}{l}\text { Aquaculture satisfies basic } \\
\text { needs and contributes to } \\
\text { landscape maintenance. It } \\
\text { has an identity and social } \\
\text { function (gift). Aquaculture } \\
\text { is considered as an econom- } \\
\text { ically vulnerable industry } \\
\text { which must be supported } \\
\text { (research or government). }\end{array}$ & $\begin{array}{l}\text { Economic functions, prof- } \\
\text { itability and growth are } \\
\text { favoured. Its food-producing } \\
\text { as well as prestige, fun } \\
\text { and leisure functions are } \\
\text { recognized. This activity is } \\
\text { considered as to have no } \\
\text { environmental impact. }\end{array}$ & $\begin{array}{l}\text { This activity is analyzed } \\
\text { based on its impacts on } \\
\text { global economic develop- } \\
\text { ment and on employment. } \\
\text { Environmental impacts are } \\
\text { taken into account and are } \\
\text { only considered as nega- } \\
\text { tive by some producers. } \\
\text { Needs for technological } \\
\text { improvement are identified. }\end{array}$ & $\begin{array}{l}\text { Social functions are not men- } \\
\text { tioned and environmental im- } \\
\text { pacts are considered as neu- } \\
\text { tral. It is a profitable activity } \\
\text { generating employment. Its } \\
\text { production is increasing and } \\
\text { is moving towards an indus- } \\
\text { trial scale. }\end{array}$ \\
\hline $\begin{array}{l}\text { Vision focused on the farm } \\
\text { and its direct environment. }\end{array}$ & $\begin{array}{l}\text { Vision focused on the farm } \\
\text { which provides a positive } \\
\text { correlation with economic } \\
\text { development. }\end{array}$ & $\begin{array}{l}\text { More global vision in which te } \\
\text { best understood }\end{array}$ & \\
\hline
\end{tabular}

Table 9. Summary of sustainable development (SD) representations according to the type of aquaculture system.

\begin{tabular}{|c|c|c|}
\hline $\begin{array}{l}\text { Multi-activity food- } \\
\text { producing farms }\end{array}$ & $\begin{array}{l}\text { Independent small } \\
\text { production farms }\end{array}$ & $\begin{array}{ll}\begin{array}{l}\text { Medium-sized } \\
\text { production farms and } \\
\text { wholesale marketing }\end{array} & \begin{array}{l}\text { Integrated "industrial" } \\
\text { farms }\end{array} \\
\end{array}$ \\
\hline $\begin{array}{l}\text { Very little knowledge of } \\
\text { SD. The only type of sys- } \\
\text { tem in which SD informa- } \\
\text { tion is not circulated in the } \\
\text { professional field but only } \\
\text { known by media. Sustain- } \\
\text { ability is expressed through } \\
\text { reinforcing the economic } \\
\text { pillar by maintaining a suf- } \\
\text { ficient AV level and by the } \\
\text { profitability of the activity. }\end{array}$ & $\begin{array}{l}\text { SD culture viewed as a } \\
\text { global equilibrium. The } \\
\text { sustainability of the activity } \\
\text { is related to the preservation } \\
\text { and creation of employ- } \\
\text { ment, to inter- and intra- } \\
\text { activity/use coherence, to } \\
\text { AV preservation and to } \\
\text { profitability, to the com- } \\
\text { patibility of fish farming } \\
\text { and the environment, and } \\
\text { to environmental impact } \\
\text { control. }\end{array}$ & $\begin{array}{l}\text { Knowledge of SD mainly comes from the professional } \\
\text { field but also from media and public authorities. They } \\
\text { have very an operational perception of SD which is de- } \\
\text { fined as using good production and management prac- } \\
\text { tices, with a very market-centred logic. This shows a } \\
\text { more commercial perception of economic sustainabil- } \\
\text { ity: preserving and increasing the value of a finished } \\
\text { product, developing exports and sales force. At a social } \\
\text { level, this involves improving the image and promot- } \\
\text { ing the profession which is underlined as well as pre- } \\
\text { serving employment. As regards environmental sus- } \\
\text { tainability, type } 3 \text { farms show that they are dependent } \\
\text { on water (quality and availability); type } 4 \text { farms have } \\
\text { a rather functional perception: environmental sustain- } \\
\text { ability is based on environmental impact control. This } \\
\text { is the only type which underlines the need for fish } \\
\text { farmer training. }\end{array}$ \\
\hline
\end{tabular}


Table 10. Distribution of farms according to the type of regulatory systems identified.

\begin{tabular}{|c|c|c|c|}
\hline $\begin{array}{l}\text { Unregulated } \\
\text { systems } \\
(58 \% \text { of farms }) \\
\end{array}$ & $\begin{array}{l}\text { Regulated systems } \\
\text { (in an informal manner) } \\
\text { (10\% of farms) }\end{array}$ & $\begin{array}{l}\text { Regulated systems } \\
\text { (in a formal manner) } \\
(16 \% \text { of farms) }\end{array}$ & $\begin{array}{l}\text { Strong formal } \\
\text { Regulation } \\
(16 \% \text { of farms) } \\
\end{array}$ \\
\hline Cameroon: 10/13 & Cameroon: $2 / 136$ & Mediterranean area: $8 / 21$ & Mediterranean area: $10 / 21$ \\
\hline Philippines: 30/30 6 & Mediterranean area: 3/ 21 & Brittany: 2/8 & Cameroon: $1 / 13$ \\
\hline Indonesia: $35 / 56$ & Indonesia: 8/56 & Indonesia: 10/56 & $\begin{array}{l}\text { Brittany: } 6 / 8 \\
\text { Indonesia: } 3 / 56\end{array}$ \\
\hline
\end{tabular}

Table 11. Summary matrix of the relative weight of representations.

\begin{tabular}{|c|c|c|c|c|c|}
\hline & & $\begin{array}{l}\text { Multi-activity food } \\
\text { food- } \\
\text { producing }\end{array}$ & $\begin{array}{l}\text { Independent } \\
\text { small production } \\
\text { marketing }\end{array}$ & $\begin{array}{l}\text { Medium-sized } \\
\text { production farms } \\
\text { and wholesale }\end{array}$ & $\begin{array}{l}\text { Integrated } \\
\text { “industrial" farms }\end{array}$ \\
\hline \multirow{4}{*}{$\begin{array}{l}\text { Representation of } \\
\text { the activity }\end{array}$} & Aspect: & & & & \\
\hline & Economic & ++ & +++ & ++++ & ++++ \\
\hline & Social & ++++ & +++ & +++ & 0 \\
\hline & Environmental & ++++ & 0 & 0 & 0 \\
\hline \multirow[t]{3}{*}{$\begin{array}{l}\text { Representation of } \\
\text { sustainability }\end{array}$} & $\begin{array}{l}\text { Factor: } \\
\text { Economic }\end{array}$ & ++++ & ++ & ++ & ++++ \\
\hline & Social & ++ & +++ & ++ & +++ \\
\hline & Environmental & ++++ & ++ & ++ & +++ \\
\hline
\end{tabular}

differences in the level of producer responsibility. This typology is useful because it highlights the factors which determine the units' implementation strategies for sustainable development. However it should be noted that certain "functional" or "technical" variables are correlated with these broad categories of aquaculture system. For instance, the first summary typology group represents farms in which labour essentially consists of the family. These are also farms in which the level of financial availability leads to limited, or even non-existent, technical changes and low production expenditures which are often restricted to feed supplies. On the other hand, these farms are strongly integrated into the local economy as they contribute to landscape maintenance, even increase the value of certain ecosystems (wetlands), and they are greatly involved in local social networks.

It must be emphasized that the regulatory systems that determine governance arrangements do not appear in this classification even though they determine the way actions towards sustainable development are carried out. However, the data relating to these variables were collected during surveys and the most significant ones were integrated into the systemic typologies. Nevertheless, the variables from this institutional component were not discriminating variables for the global classification. These variables only appear in the functional typology at the formal constraint level, in particular in relation to site access which is often a highly regulated element. The fact that a specific classification covering all the characteristics of institutional systems, including three components: the decisionmaking system, the implementation mechanism(s) and the information system, has been developed in parallel should be highlighted. This analysis makes it possible to characterize aquaculture systems according to an ascending regulatory gradient, depending on the more or less formal nature of regulations and on the dynamism of professional bodies together with the level of regulatory constraint and the frequency of controls. Four types can be observed (Table 10): Unregulated systems (58\%), Regulated systems (in an informal manner $(10 \%)$ ), Regulated systems (in a formal manner (16\%)) and Strong formal regulation (16\%) (Chia et al. 2008). Similarly, in order to compare institutional effectiveness of global seafood consumption across countries, Smith et al. (2010) used an average of four governance indicators developed for the World Bank as a proxy.

Moreover, these results are not far from the types of representation that actors have of their activity and of sustainable development. We have assumed that if fish farmers' representation of sustainable development is close to the representation that they have of their activity and their role in the local economy, then the chances of implementing sustainable development are higher. Representations were compared with the aim of constructing a comparative matrix (Table 11) of the views of each fish farmer regarding his impact on the different aspects of the aquaculture activity and on the factors which he highlights as important in implementing the sustainable development of the activity. This matrix validates the typology results by showing that the groups identified make sense for the actors. These latter understand sustainable development according to the nature of the interactions with the ecological and economic environment. It must also be noted that two extreme categories (multi-activity food-producing farms and integrated "industrial" farms) are those where sustainable development is the most appropriated, either because the units' characteristics entail a strong integration with the ecological, economic and social environment (multi-activity, food-producing farms) or because it is a strategic element in farm management through pro-active strategies (integrated "industrial" farms) in particular as the development of new organic practices is a major issue for these farms. 


\section{Conclusion}

The results show that the approach presented is genuinely innovative, both in the broad range of variables taken into account to define aquaculture systems and in the fact that this approach correlates these variables with actors' representations. This method is based on successively ranking discriminating variables and on the significance of non response rates recorded in survey results regarding institutional variables which are less familiar for the fish farmers surveyed. Statistical tools (e.g. Multiple Correspondence Analysis) were combined with comprehensive analysis and we proceeded in stages in order to select the most relevant and/or discriminating variables. This approach made it possible to build on the knowledge acquired by researchers and "experts" about the way in which aquaculture farms and production zones operate. The principal result of this analysis is to show that the size and as a consequence the nature of unit management (in particular property arrangements and sales circuits) are the determinant factors for unit types and the ways in which they represent sustainable development. It is essential that these factors and these differences are taken into account in the definition of public policies promoting sustainable aquaculture, in particular to allow for the definition of specific conditions according to the four large categories of aquaculture system identified: multiactivity food producing farms, independent small production farms, medium-sized production farms and wholesale marketing, integrated "industrial" farms. Another innovative element of the approach is to take into account aquaculture's contribution to the sustainability of the areas where it is established. The results show that this approach accords with the way actors perceive the relationships with the ecological and social environment of the activity and that it covers all the identified types of aquaculture. This approach requires, both sectorally and regionally, an integrated approach to aquaculture, which, for example, must also be considered in terms of the services rendered to the areas where the aquaculture systems are established and in terms of the acceptability and the social recognition of the value placed on these services by society, and then by fish farmers. Thus, the integration of ecosystems is considered as both a resource and a natural asset allowing the production of ecological and economic services for society, whose interactions with aquaculture farming systems must be addressed through ecosystem approaches (UICN et al. 2004; Millennium Ecosystem Assessment 2005; FAO 2008b).

Acknowledgements. The results reported in this article were obtained in the framework of the "EVAD" Project ("Evaluation of aquaculture systems sustainability") developed from 2005 to 2009 within the "Agriculture and Sustainable Development" Programme of the French National Research Agency (ANR, Agence Nationale de la Recherche).

\section{References}

Allsopp M., Johnston P., Santillo D., 2008, Greenpeace Research Laboratories Technical Note 01/2008. Amsterdam, Greenpeace.
Belton B., Little D., Grady K., 2009, Is responsible aquaculture sustainable aquaculture? WWF and the Eco-Certification of Tilapia. Soc. Nat. Resour. 22, 840-855.

Bodiguel C., Rey-Valette H., 2006, Gestion intégrée du couple pêchetourisme sur le littoral : réflexion prospective selon le degré de spécialisation des territoires. In "Pêche et Aquaculture. Pour une exploitation durable des ressources vivantes de la mer et du littoral :Gestion intégrée et dynamiques territoriales". Presses Univ. Rennes, pp. 367-379.

Boyd C.E., McNevin A.A., Clay J., Johnson H.M., 2005, Certification issues for some common aquaculture species. Rev. Fish. Sci. 13, 231-279.

Boyd C.E., Lim, C., Queiroz J., Salie K., De Wet L., McNevin A., 2008, Best management practices for responsible aquaculture. In: USAID/Aquaculture Collaborative Research Support Program, Corvallis, Oregon State University, 47 p.

Chevassus-au-Louis B., Lazard J., 2009, Perspectives pour la recherche biotechnique en pisciculture. Cah. Agric. 18, 91-96.

Chia E., Rey-Valette H., Mathé S., 2008, Aquaculture and sustainable development: between regulation and governance systems. Int. J. Sustain. Dev. 11, 138-153.

Costa-Pierce B.A. (Ed.), 2002, Ecological aquaculture: The evolution of the blue revolution. Malden, MA, Blackwell Science Ltd.

Couty P., 1984, La vérité doit être construite. Cah. Orstom Sér. Sci. Hum. 20, 5-15.

Dey M.M., Rab M.A., Paraguas F.J., Piumsombun S., Bhatta R., Alam M.F., Ahmed M., 2005, Fish consumption and food security: A disaggregated analysis by types of fish and classes of consumers in selected Asian countries. Aquac. Econ. Manage. 9, 89-111.

De Silva S.S., Davy F.B., 2009, Aquaculture successes in Asia, contributing to sustained development and poverty alleviation. In: De Silva S.S., Davy F.B. (Eds.) Success Stories in Asian Aquaculture, Doordrecht, Germany, Springer-NACA-IDRC, pp. $1-14$.

FAO ProdSTAT, 2008a, Livestock (primary and processed), FAOSTAT, FAO, Rome.

FAO, 2008b, Building an ecosystem approach to aquaculture. Soto D., Aguilar-Manjarrez J., Hishamunda N. (Eds.). FAO Fisheries and Aquaculture Proceedings 14, Rome.

FAO, 2009, La situation mondiale des pêches et de l'aquaculture. Département des pêches et de l'aquaculture de la FAO, Rome.

Hejdova E., 2006, L'enchâssement social de l'accès à la terre et au financement : l'exemple des entreprises aquacoles aux Philippines, Colloque "Les frontières de la question foncière : Enchâssement social des droits et politiques publiques", Montpellier, 2006. http://www.mpl.ird.fr/colloque_ foncier/Communications/PDF/Hejdova.pdf

Irz X.T., Stevenson J.R., 2004, Is there an efficiency case for land redistribution in Philippine brackish-water aquaculture? Analysis in a ray production frontier framework. Stirling (UK): DFID Aquaculture and Fish Genetics Research Programme. http:// www.dfid.stir.ac.uk/Afgrp/projects/r8288/WP5R8288.pdf

Irz X.T., Stevenson, J.R., Tanoy, A., Villarante, P., Morissens, P., 2007, The equity and poverty impacts of aquaculture: insights from the Philippines. Dev. Policy Rev. 25, 495-516.

Jodelet D., 1989, Les représentations sociales. Paris, Presses Universitaires de France.

Kaplowitz M.D., 2000, Identifying ecosystem services using multiple methods: Lessons from the mangrove wetlands of Yucatan, Mexico. Agric. Human Values 17, 169-179.

Lazard J., Lévêque C., 2009, Introductions et transferts d'espèces de poissons d'eau douce. Cah. Agric. 18, 57-163. 
Lazard J., Lecomte Y., Stomal B., Weigel J.Y., 1991, Pisciculture en Afrique Subsaharienne. Paris, France, Ministère français de la Coopération et du Développement.

Michielsens C.G.J., Philips M., Lorenzen K., Gauthier R., 2002, Asian carp farming systems : Towards a typology and increased resource use efficiency. Aquac. Res. 33, 403-413.

Millenium Ecosystem Assessment, 2005, Ecosystems and Human Well-being. Wetlands \& Water. Washington DC, Island Press.

Naylor R.L., Goldberg R.J., Primavera J.H., Kautsky N., Beveridge M.C.M., Clay J., Folke C., Lubchenco J., Mooney H., Troell M., 2000, Effects of aquaculture on world fish supplies. Nature 405, 1017-1024

Pemsl D.E., Dey M.M., Paraguas F.J., Lal Bose M., 2006, Determining high potential aquaculture production areas: analysis of key socio-economic adoption factors. In: Proc. 13th Biennial Conference of the IIFET, July 11-14, 2006, Portsmouth, UK: Rebuilding Fisheries in an Uncertain Environment. Compiled by A.L. Shriver. IIFET, Corvallis, Oregon, USA, CD ROM ISBN 0-97632432-3-1.

Rey-Valette H., Clément O., Aubin J., Mathé S., Chia E., Legendre M., Caruso D., Mikolasek O., Blancheton J.P., Slembrouck J., Baruthio A., René F., Levang P., Morissens P., Lazard J., 2008, Guide to the co-construction of sustainable development indicators in aquaculture. Montpellier, Cirad.

Rey-Valette H., Blancheton J.P., René F., Lazard J., Mathé S., Chia E., 2007, Le développement durable : un défi pour l'aquaculture marine en Méditerranée. Cah. Agric. 16, 1-10.

Ronnback P., Bryceson I., Kautsky N., 2002, Coastal aquaculture development in Eastern Africa and the Western Indian Ocean: Prospects and problems for food security and local economies. Ambio 31, 537-542.

Smith M.D., Roheim C.A., Crowder L.B., Halpern B.S., Turnipseed M., Anderson J.L., Asche F., Bourillon L., Guttormsen A.G., Khan A., Liguori L.A., McNevin A., O'Connor M.I., Squires D., Tyedmers P., Brownstein C., Carden K., Klinger D.H., Sagarin R., Selkoe K.A., 2010, Sustainability and global seafood. Science 327 (12 February), 784-786.

Stevenson J.R., Irz X.T., Alcalde R.G., Morissens P., Petit J., 2007, An empirical typology of brackish-water pond aquaculture systems in the Philippines: a tool to aid comparative study in the sector. Aquac. Econ. Manage. 11, 171-193.

Stickney K.I., McVey J.P. (Eds.), 2002, Responsible Marine Aquaculture, New York, CABI Publishing.

Svasand T., Crosetti D., Garcia-Vasquez E., Verspoor E. (Eds.), 2007, Genetic impact of aquaculture activities on native populations.
Genimpact final scientific report, EU contract $\mathrm{n}^{\circ}$ RICA-CT2005-022802, http://genimpact.imr.no/.

Tacon A.G.J., Metian M., 2008, Global overview on the use of fish meal and fish oil in industrially compounded aquafeeds: Trends and future prospects. Aquaculture 285, 146-158.

Tacon A.G.J., Metian M., Turchini G.M., De Silva S.S., 2010, Responsible aquaculture and trophic level implications to global fish supply. Rev. Fish. Sci. 18, 94-105.

Tett P., 2008, Fish farm wastes in the ecosystem. In: Holmer M., Black K., Duarte C.M., Marba N., Karakasis I. (Eds.) Aquaculture in the ecosystem, Doordrecht, Springer.

UICN, World Bank and The Nature Conservancy, 2004, How much is an ecosystem worth ? Assessing the economic value of conservation. Washington, DC, The International Bank for Reconstruction and Development/The World Bank.

Umesh N.R., Chandra Mohan A.B., Ravibabu G., Padiyar P.A., Phillips M.J., Mohan C.V., Vishnu Bhat B.B., 2009, Implementation of better management practices by empowering small-scale farmers through a cluster-based approach: The case of shrimps farmers in India. In: De Silva S.S., Davy F.B. (Eds.) Success Stories in Asian Aquaculture, Doordrecht, SpringerNACA-IDRC, pp. 43-68.

Yap W.G., 1999, Rural Aquaculture in the Philippines. Rome, Italy, FAO/RAP Publication. http://www.fao.org/fishery/countrysector/ naso_philippines/fr

Viswanathan K., Genio E., 2001, Socioeconomics of responsible aquaculture in Asia, In: Garcia L.M.B. (Ed.) Proceedings of the Seminar-Workshop on Responsible Aquaculture Development in Southeast Asia. SEAFDEC Aquaculture Department, 12-14 October 1999, Iloilo City, Philippines, Southeast Asian Fisheries Development Centre (SEAFDEC), pp. 89-97.

Wagner B.A., Young J.A., 2009, Sea bass and sea bream farmed in the Mediterranean: swimming against the tide of market orientation. Supply Chain Manage.-Int. J. 14, 435-446.

World Bank, 2007, Aquaculture: Changing the face of the waters meeting the promise and challenges of sustainable aquaculture. Washington DC, The World Bank, Agriculture and Rural Development, Report No. 36622-GLB.

WWF (World Wildlife Fund), 2007, Benchmarking Study: Certification Programmes for Aquaculture. Environmental Impacts, Social Issues and Animal Welfare. (http://assets. panda.org/downloads/benchmarking_study_wwf_aquaculture_ standards_new_pdf). 